\title{
Kilkupoziomowa niedrożność przewodu pokarmowego u młodej pacjentki powstała wkrótce po porodzie - opis przypadku
}

\section{A multilevel obstruction of the digestive tract in a young female patient soon after delivery: a case report}

\author{
Andrzej Żyluk ${ }^{\bowtie}$, Wojciech Jagielski, Piotr Janowski \\ Pomorski Uniwersytet Medyczny w Szczecinie, Klinika Chirurgii Ogólnej i Chirurgii Ręki, ul. Unii Lubelskiej 1, 71-252 Szczecin \\ $\triangle$ azyluk@hotmail.com
}

\begin{abstract}
The article reports the case of a 31-year-old patient, in whom bowel ileus developed 2 days after natural delivery, and who in the second trimester underwent laparotomy due to mechanical obstruction involving the duodenum and small bowel and caused by swallowed foreign bodies. The course of pregnancy from the operation to delivery was uneventful. Preoperative diagnostics (barium meal) showed features of mechanical obstruction involving the duodenum and small bowel. The patient underwent surgery, and abdominal exploration revealed a largely distended duodenum filled by thick contents, dilated and involved in massive adhesions in the small bowel and a largely distended proximal colon. No site of critical stenosis of the bowel was found, and
\end{abstract}

no other cause of disturbed intestinal passage was identified. Intraoperatively, no peristalsis was observed in the small bowel, although it was heard at abdominal auscultation before surgery. As adhesion release did not resolve the problem, a decision was made to discharge the small bowel and proximal colon by an incision of the caecum, followed by the formation of a cecostomy. Postoperative course was complicated by short episodes of upper digestive tract bleeding and diarrhoea, which disappeared soon after conservative therapy. The patient eventually recovered, and further gastroenterological investigations were inconclusive.

Keywords: bowel obstruction; unknown aetiology; confinement.

\begin{abstract}
ABSTRAKT
W pracy opisano przypadek 31-letniej kobiety, u której niedrożność jelit rozpoczęła się 2 dni po porodzie drogą naturalną. Pacjentka w II trymestrze ciąży miała wykonaną laparotomię z powodu niedrożności mechanicznej dwunastnicy i jelita cienkiego wywołanej połkniętymi ciałami obcymi. Przebieg ciąży od operacji do porodu był niepowikłany. Przedoperacyjna diagnostyka radiologiczna (pasaż) wykazała niedrożność mechaniczną dwunastnicy i jelita cienkiego. Pacjentka była operowana. Śródoperacyjnie stwierdzono bardzo powiększoną, wypełnioną gęstą treścią pokarmową dwunastnicę, poszerzone jelito cienkie w masywnych zrostach międzyjelitowych i znacznie poszerzoną początkową część okrężnicy. W żadnym miejscu nie znaleziono
\end{abstract}

jednak krytycznego zwężenia jelita ani innej przyczyny zaburzenia pasażu treści jelitowej. Jelito cienkie w czasie operacji nie wykazywało perystaltyki, jednak przed operacją osłuchiwanie wykazało jej obecność. Ponieważ uwolnienie jelita ze zrostów nie rozwiązało problemu, zdecydowano się na odbarczenie jelita cienkiego i okrężnicy przez nacięcie kątnicy i następnie na wyłonienie cekostomii. Przebieg pooperacyjny był powikłany epizodem krwawienia z górnej części przewodu pokarmowego i biegunką, które jednak szybko ustąpiły po leczeniu zachowawczym. Pacjentka powróciła do zdrowia, a późniejsza diagnostyka gastroenterologiczna nie wykazała jednoznacznej patologii w przewodzie pokarmowym.

Słowa kluczowe: niedrożność jelit; nieznana przyczyna; połóg.

\section{WSTĘP}

Niedrożność jelit/przewodu pokarmowego oznacza zaburzenie przechodzenia (pasażu) treści pokarmowej przez przewód pokarmowy. Ogólnie niedrożność dzieli się na czynnościową (porażenną) i mechaniczną. Podejrzenie niedrożności mechanicznej jelit jest jednym z częstszych powodów skierowań na oddział chirurgiczny, a jej typowe objawy: ból brzucha, zatrzymanie stolca i gazów, wymioty i wzdęcie brzucha są znane każdemu lekarzowi (choć nie zawsze prawidłowo interpretowane). Najczęstszą przyczyną niedrożności mechanicznej są zrosty wewnątrzbrzuszne powstałe w następstwie przebytych operacji (niedrożność zrostowa) [1]. W pracy opisano przypadek pacjentki, u której niedrożność jelit rozpoczęła się 2 dni po porodzie drogą naturalną i która w 4. miesiącu ciąży miała wykonaną laparotomię z powodu niedrożności mechanicznej dwunastnicy i jelita cienkiego wywołanej ciałami obcymi.

Przebieg choroby, jej nieustalony charakter, spostrzeżenia śródoperacyjne i rozwiązanie problemu wydają się autorom na tyle oryginalne i niespotykane, że warte opisania i publikacji.

\section{SPOSTRZEŻENIE WŁASNE}

Na Szpitalny Oddział Ratunkowy w godzinach wieczornych zgłosiła się 31-letnia pacjentka z objawami niedrożności mechanicznej przewodu pokarmowego. Trzy dni wcześniej 
w innym szpitalu urodziła siłami natury zdrowego noworodka. Dolegliwości zaczęły się rano w dniu przyjęcia - najpierw ból brzucha, następnie wymioty, wzdęcie i zatrzymanie gazów. Pacjentka była w stanie ogólnym dobrym, cierpiąca, wymioty były sporadyczne, nieobfite, treścią żołądkową. Przeglądowe zdjęcie RTG jamy brzusznej uwidoczniło poszerzone pętle jelita cienkiego z poziomami płynu, co wskazywało na niedrożność mechaniczną jelita cienkiego. Z wywiadu stwierdzono, że 4 miesiące wcześniej, będąc w 5. miesiącu ciąży, pacjentka była operowana z powodu dwupoziomowej niedrożności mechanicznej (dwunastnicy i jelita cienkiego) spowodowanej ciałami obcymi (bezoarami) niejasnego pochodzenia, które zostały ewakuowane z jelit przez ich nacięcie. W trakcie operacji stwierdzono znaczne poszerzenie wypełnionej ciałami obcymi dwunastnicy, która sięgała aż do prawego podbrzusza. Po operacji pacjentka była hospitalizowana na oddziale psychiatrycznym z powodu podejrzenia połknięcia ciał obcych i wcześniejszych epizodów anoreksji i bulimii, jednak nie rozpoznano u niej żadnych zaburzeń psychicznych. Ponieważ obraz kliniczny wskazywał na niedrożność przepuszczającą o etiologii zrostowej, pacjentkę przyjęto w godzinach nocnych na oddział chirurgiczny, wdrożono pasaż przewodu pokarmowego i leczenie zachowawcze.

Następnego dnia rano stan pacjentki nie uległ zmianie, z sondy ewakuowało się ok. 200 mL treści żołądkowej o charakterze zastoinowym. Wykonane w ciągu nocy 2 lewatywy były nieskuteczne. Osłuchiwanie jamy brzusznej wykazywało żywą perystaltykę o „metalicznej” tonacji. Zdjęcie pasażu po 8 godz. od jego wdrożenia wykazało obecność środka cieniującego w żołądku i brak jego przejścia do dwunastnicy (ryc. 1 i 2). Jednocześnie na zdjęciach stwierdzono obecność cienia w prawym nadbrzuszu, który mógł odpowiadać bardzo powiększonej dwunastnicy, wypełnionej - jak przy poprzedniej operacji ciałami obcymi (ryc. 1 i 2). Pacjentka zdecydowanie zaprzeczała, jakoby połknęła jakieś substancje w ciągu ostatnich dni. Niezależnie od braku przejścia kontrastu do dwunastnicy całe jelito cienkie było bardzo poszerzone, co wskazywało na jeszcze jeden poziom niedrożności, w jego końcowej części. W takiej sytuacji zdecydowano o powtórnej próbie podania środka cieniującego rozpuszczalnego w wodzie do żołądka i obserwowaniu jego zachowania pod monitorem RTG. Wynik badania przedstawiono na rycinie 3: środek cieniujący wypełnił początkową część (opuszkę) dwunastnicy i nie przechodził dalej. Mając taki obraz kliniczny i radiologiczny, zdecydowano o podjęciu leczenia operacyjnego.

\section{SPOSTRZEŻENIA ŚRÓDOPERACYJNE}

Jamę brzuszną otwarto przez bliznę po poprzednim cięciu pośrodkowym w śródbrzuszu. Jelito cienkie było znacznie poszerzone i miało liczne zrosty, które mozolnie zwalniano. Nie stwierdzono jednego krytycznego zrostu, który mógłby spowodować niedrożność, a ciekawym spostrzeżeniem była obecność normalnych, nieposzerzonych odcinków jelita cienkiego między znacznie rozdętymi. Po uwolnieniu całego jelita cienkiego odsłonięto prawą flankę jamy brzusznej i wypreparowano znacznie poszerzoną, wypełniona gęstą treścią dwunastnicę, co potwierdziło podejrzenie wysunięte $\mathrm{w}$ badaniu radiologicznym (ryc. 1-3). Nie stwierdzono jednak w jej obrębie stałych ciał obcych (jak w poprzedniej operacji), udało się natomiast przepchnąć gęstą zawartość dwunastnicy do żołądka, skąd została odessana przez sondę. Była to gęsta, cuchnąca treść o charakterze jelitowym. Znaczne poszerzenie dwunastnicy dotyczyło jej części zstępującej i częściowo poziomej, a pozostały (dalszy) odcinek do więzadła Treiza wyglądał normalnie, bez żadnego miejsca zwężenia lub ucisku.

Kontynuowano preparowanie jelita cienkiego ze zrostów w kierunku dalszym, aż do kątnicy, nie stwierdzając żadnego miejsca zwężenia. Jelito końcowe przed kątnicą było umiarkowanie poszerzone. Kątnica tkwiła w zrostach w prawym dole biodrowym, a po jej odreparowaniu okazało się, że jest znacznie

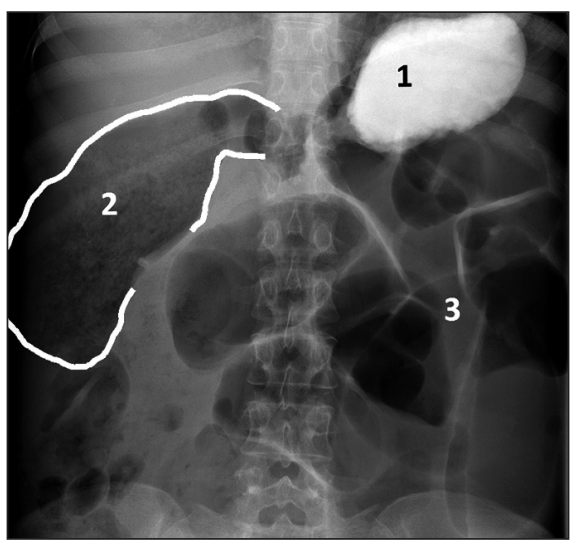

RYCINA 1. Zdjęcie RTG jamy brzusznej 1 godz. po rozpoczęciu pasażu przewodu pokarmowego (połknięciu środka cieniującego): 1 - środek cieniujący w żołądku; 2 - zarys powiększone dwunastnicy; 3 - poszerzone pętle jelita cienkiego (zdjęcie wykonane w pozycji leżącej)

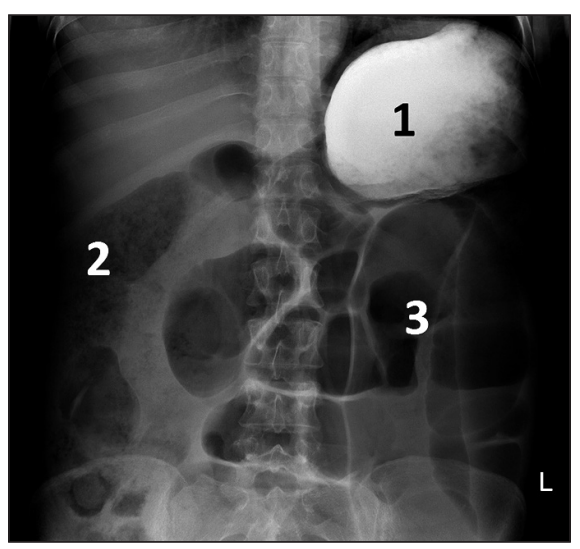

RYCINA 2. Zdjęcie RTG jamy brzusznej 8 godz. po rozpoczęciu pasażu przewodu pokarmowego: 1 środek cieniujący w żołądku; 2 - cień powiększonej dwunastnicy; 3 - poszerzone pętle jelita cienkiego (zdjęcie wykonane w pozycji leżącej)

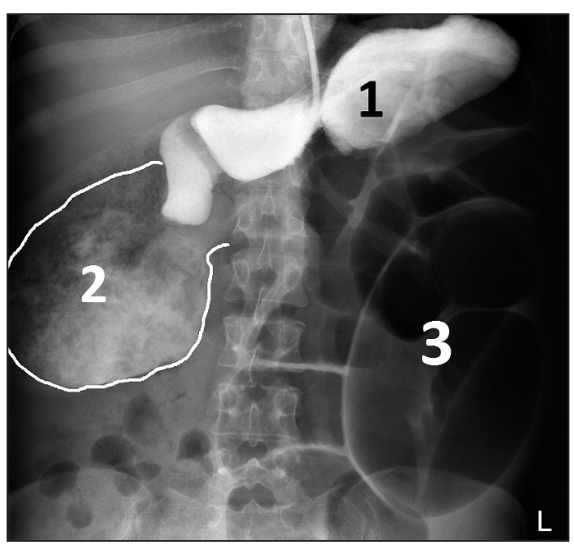

RYCINA 3. Zdjęcie jamy brzusznej z badania kontrastowego pod monitorem RTG. Środek cieniujący rozpuszczalny w wodzie podawany przez sondę: 1 - środek cieniujący w żołądku i opuszce dwunastnicy; 2 - zarys powiększonej dwunastnicy; 3 poszerzone pętle jelita cienkiego (zdjęcie wykonane w pozycji leżącej) 
poszerzona, do $12 \mathrm{~cm}$ w wymiarze poprzecznym. Poszerzona była także wstępnica, ale w mniejszym stopniu, natomiast zmniejszało się ona w kierunku dalszym tak, że poprzecznica wyglądała normalnie. Ciekawym spostrzeżeniem był brak widocznej perystaltyki jelitowej w czasie operacji (normalnie perystaltyka jelita cienkiego jest widoczna).

W tym momencie operacji, po wypreparowaniu jelit z licznych zrostów, należało podjąć decyzję, co robić dalej w sytuacji, kiedy nie stwierdzono żadnego krytycznego miejsca zwężenia lub ucisku odpowiedzialnego za niedrożność, a jednocześnie obraz śródoperacyjny wskazywał na niedrożność na 3 poziomach: dwunastnicy, jelita cienkiego i kątnicy/wstępnicy. Ostatecznie podjęto decyzję o odbarczeniu (ewakuacji zawartości) jelita cienkiego przez otwór w kątnicy, którą - ze względu na jej rozmiary - można było wyciągnąć ponad powłoki brzuszne, aby nie zanieczyścić jamy otrzewnowej. Najpierw ewakuowano ok. 1 L treści kałowej ze wstępnicy i kątnicy, a następnie „wyciśnięto" etapami ok. 3 L zawartości z jelita cienkiego. Po udanym odbarczeniu jelit pozostawało pytanie, czy będzie ono w stanie powrócić do aktywności motorycznej wystarczającej do normalnego funkcjonowania. Ze względu na brak widocznej perystaltyki zdecydowano o wyłonieniu kątnicy (cekostomii), co w założeniu miało ułatwić opróżnianie się jelita cienkiego przez wyeliminowanie oporu okrężnicy. Z uwagi na znaczne rozmiary kątnicy wyłoniona cekostomia nie zaburzała pasażu treści pokarmowej do wstępnicy.

\section{PRZEBIEG POOPERACYJNY}

Przebieg pooperacyjny był powikłany w 2 . dobie epizodem krwawienia z górnego odcinka przewodu pokarmowego, pod postacią obecności treści fusowatej w sondzie, spadku ciśnienia tętniczego do 80-90/50-60 mmHg i anemizacji, które w ciągu 2 dni ustąpiło samoistnie. Pacjentka otrzymała standardowe leczenie inhibitorem pompy protonowej (pantoprazol) i przetoczono jej 2 jednostki koncentratu krwinek czerwonych. W kolejnych dobach jej stan się systematycznie poprawiał, z cekostomii ewakuowało się najpierw ok. 1,5-2 L płynu jelitowego, aby w 5.-6. dobie zmniejszyć się do ok. 500-600 mL. Z uwagi na brak zalegania w żołądku w 3 . dobie pooperacyjnej usunięto sondę i wdrożono żywienie doustne. Od 4. doby u pacjentki wystąpiła biegunka (10-12 wodnistych stolców na dobę), która trwała 3 dni i ustąpiła po leczeniu objawowym loperamidem. W 2. dobie pooperacyjnej ( $5 \mathrm{dni}$ po porodzie) pacjentka była konsultowana przez ginekologa, który zalecił leczenie wstrzymujące laktację. W 7. dobie pacjentkę przekazano w stanie dobrym na oddział gastroenterologiczny, gdzie wykonano endoskopię, za pomocą której wykazano zapalenie dolnej części przełyku i zmiany nieżytowe błony śluzowej żołądka. Stwierdzono także znacznie powiększoną dwunastnicę ze zmianami zapalnymi błony śluzowej, jednak nie udało się zbadać jej całej z uwagi na zaleganie treści pokarmowej, mimo uważnego przygotowania pacjentki (w dniu poprzedzającym badanie jadła tylko śniadanie). Wykonano także enteroklizę, która potwierdziła znaczne powiększenie dwunastnicy, ale nie wykazała zmian patologicznych w obrębie jelita cienkiego. Pacjentka została wypisana do domu po 13 dniach od przyjęcia do szpitala i pozostaje pod kontrolą ambulatoryjną. Oddaje stolec drogą naturalną co $2 \mathrm{dni}$, a z cekostomii ewakuuje się 300-400 mL płynnej treści kałowej.

\section{OMÓWIENIE}

Opisywany przypadek jest interesujący ze względu na:

- trzypoziomową niedrożność przewodu pokarmowego o nieustalonej etiologii i nieokreślonym charakterze (mechaniczna czy czynnościowa?),

- wystąpienie objawów bezpośrednio po porodzie i ich brak w czasie ciąży (po operacji w 4. miesiącu), kiedy ucisk na jelito przez powiększoną macicę powinien sprzyjać ich powstaniu,

- znaczne powiększenie 2 części przewodu pokarmowego dwunastnicy i kątnicy bez określonej przyczyny,

- szybkie ustąpienie objawów niedrożności po operacji, która nie wykazała jej jednoznacznej przyczyny.

Biorąc pod uwagę bardzo dużą liczbę zrostów w jamie otrzewnowej, można by przypuszczać, że niedrożność miała charakter mechaniczno-zrostowy. Przeczy temu jednak niestwierdzenie miejsca (lub miejsc) krytycznego zwężenia jelita powodujących przerwanie pasażu. Ponadto śródoperacyjne poszerzenie jelit stwierdzono na 3 różnych poziomach i na żadnym z nich nie wykryto przyczyny tego zjawiska. Na czynnościowy charakter niedrożności mógłby wskazywać brak perystaltyki jelitowej w trakcie operacji. Jednak osłuchiwanie jamy brzusznej przed operacją wykazało żywą, „,niedrożnościową” perystaltykę. Zatem charakteru i przyczyny tej niedrożności nie udało się wyjaśnić ani przed operacją, ani po operacji.

Drugą ciekawą kwestią był wybór rozwiązania operacyjnego tego nietuzinkowego problemu. W typowej niedrożności zrostowej zwolnienie przeszkody (zrostu) i przesunięcie zawartości jelita w kierunku dalszym zwykle wystarcza do udrożnienia jelita i zakończenia operacji. Przy zadzierzgnięciu i niedokrwieniu części jelita niezbędna jest jego resekcja i zespolenie w zdrowych granicach. Jednak w opisywanym przypadku uwolnienie całego jelita cienkiego ze zrostów nie stworzyło warunków do jego odbarczenia, ponieważ początek okrężnicy był znacznie poszerzony i wypełniony treścią. Wydaje się zatem, że decyzja o odbarczeniu jelita cienkiego i początku grubego przez nacięcie kątnicy była optymalna. Utworzenie cekostomii było motywowane dwiema przesłankami: po pierwsze, jeżeli jelito cienkie nie podjęłoby skutecznej funkcji (perystaltyki), przepchnięcie zawartości przez jelito grube mogłoby być utrudnione i sytuacja wróciłaby do punktu wyjściowego. Wtedy, przy poszerzeniu się kątnicy, mógłby się rozejść zszyty w niej otwór. Dlatego wyłonienie cekostomii było rozwiązaniem bezpieczniejszym i - jak się okazało - skutecznym. Rozważano także wykonanie ileostomii pętlowej na końcowej części jelita cienkiego, ale skutkowałaby ona przerwaniem pasażu do jelita grubego i wymagała później operacyjnego zamknięcia. Przy tak powiększonej kątnicy cekostomia 
pozwalała na swobodny pasaż do dalszych części okrężnicy i pozostawiała nadzieję na samoistne zamknięcie przetoki.

\section{DYSKUSJA}

W piśmiennictwie nie znaleziono opisu podobnego przypadku. Opisywane były epizody niedrożności porażennej indukowanej lekami przeciwpsychotycznymi u chorych leczonych psychiatrycznie, jednak dzięki prawidłowemu rozpoznaniu nie wymagali oni interwencji chirurgicznej [2, 3]. Opisywana pacjentka nie przyjmowała żadnych leków z takiej grupy. W innej pracy autorzy opisali przypadek młodej pacjentki z zespołem MELAS (mitochondriopatia), u której choroba objawiała się epizodami niedrożności porażennej jelit. Wyniki badań biochemicznych wykazały kwasicę mleczanową, której przyczyną mógł być zwiększony katabolizm. Autorzy opisują interesujące rozwiązanie tego problemu przez wysokokaloryczne żywienie pozajelitowe, które skutkowało powrotem perystaltyki i ustąpieniem objawów w ciągu kilku godzin [4]. W innych 2 pracach autorzy opisują niekonwencjonalne sposoby leczenia uporczywej niedrożności porażennej u pacjentów po operacjach w obrębie jamy brzusznej, za pomocą ciągłego znieczulenia zewnątrzoponowego i terapii hiperbarycznej $[5,6]$. W jednej pracy autorzy analizowali najczęstsze przyczyny pilnej interwencji chirurgicznej u ciężarnych. Zidentyfikowano 20 kobiet, które były operowane w ciąży, najczęściej z powodu ostrego zapalenia wyrostka robaczkowego $(n=6)$ i niedrożności mechanicznej na tle zrostowym $(n=3)$. Autorzy podkreślają przydatność tomografii rezonansu magnetycznego w diagnostyce ostrych chorób chirurgicznych jamy brzusznej u ciężarnych, kiedy standardowa diagnostyka radiologiczna (RTG przeglądowe i tomografia komputerowa) jest przeciwwskazana, a USG nie wyjaśnia wątpliwości [7]. Wszystkie te publikacje dotyczyły jednak innych problemów niż przedstawione w niniejszej pracy.

\section{PIŚMIENNICTWO}

1. Żyluk A. Niedrożność jelit. In: Żyluk A, editor. Zarys chirurgii dla studentów i lekarzy w trakcie specjalizacji. Warszawa: MediPage; 2016. p. 181-7.

2. Dome P, Teleki Z, Kotanyi R. Paralytic ileus associated with combined atypical antipsychotic therapy. Prog Neuropsychopharmacol Biol Psychiatry. 2007;31(2):557-60.

3. Kwiatkowski M, Denka ZD, White CC. Paralytic ileus requiring hospitalization secondary to high-dose antipsychotic polypharmacy and benztropine. Gen Hosp Psychiatry 2011;33(2):200.e5-7. doi: 10.1016/j.genhosppsych.2010.10.005.

4. Seessle J, Stremmel W, Ebinger F, Merle U. An unusual case of paralytic ileus. Z Gastroenterol 2012;50(11):1161-5. doi: 10.1055/s-0032-1313125.

5. Huang CC, Hsu HH, Huang JY, Lao HC, Cheng JK, Chen CC, et al. Treating a patient with intractable paralytic ileus using thoracic epidural analgesia. Acta Anaesthesiol Taiwan 2012;50(2):78-80. doi: 10.1016/j. aat.2012.05.005.

6. Ambiru S, Furuyama N, Kimura F, Shimizu H, Yoshidome H, Miyazaki M, et al. Hyperbaric oxygen therapy as a prophylactic and treatment against ileus and recurrent intestinal obstruction soon after surgery to relieve adhesive intestinal obstruction. J Gastroenterol Hepatol 2008;23: e379-83.

7. Unal A, Sayharman SE, Ozel L, Unal E, Aka N, Titiz I, et al. Acute abdomen in pregnancy requiring surgical management: a 20-case series. Eur J Obstet Gynecol Reprod Biol 2011;159(1):87-90. doi: 10.1016/j.ejogrb. 2011.07.028.

\section{KOMENTARZ}

Praca kazuistyczna w medycynie jest wyjątkową formą w epoce zdominowanej przez terror metody opartej na dowodach, które są przecież suboptymalne i zawsze interpretowane jako walidujące uniwersalnie. Sztuka, jaką jest medycyna, znajduje swój matecznik w indywidualnym unikalnym powiązaniu osoby chorego z lekarzem humanizującym, wrażliwym, czujnym obserwatorem. Dzięki temu kazuistyka istnieje w ogóle i ma prawo być opisana adekwatnie.

prof. dr hab. n. med. Ireneusz Kojder 